Theories \& Applications, the International Edition

Printed Version : (ISSN 2090-5262)

Online Version : (ISSN 2090-5270)

November 2014, Volume 4, No. 3 Pages (9 - 14)

\title{
Training Program According to Energy Production Systems to Improve Aerobic and Anaerobic Ability and Defense Performance Endurance and Body Composition for Hand Ball Players.
}

\author{
Dr. Tarek Mohamed Ali El-Nosery
}

Assistant professor, Department of Games , Faculty of Physical Education, Sadat City University, Egypt.

\begin{abstract}
The research aims to designing a suggested training program according to energy production systems and identifying the influence of suggested training program an aerobic and anaerobic ability of hand ball players, the influence of suggested training program on enduring attack performance of hand ball players, the influence of suggested training program on body composition of hand ball players, The total researcher sample included of ( 32 ) player were chosen by intentional way and it included all the players of 6-October city club, result; there is a significant statistical difference between the averages of per and post for the post measurements in improving aerobic and anaerobic ability for hand ball players . there is a significant statistical difference between the averages of per and post for the post measurements in the variables of attack performance endurance for hand ball players. there is a significant statistical difference between the averages of per and post for the post measurements in body weight, fat percentage, fat weight, accepted fat weight and ideal weight, while there is no statistical significant difference In free fat body weight for hand ball players . the increasing in performance improvement according to measuring unit in aerobic and anaerobic ability and attack performance endurance ( movement performance endurance - shooting on goal-medical ball throwing $1 \mathrm{Kg}$ for the longest distance - jumping from static) for research sample individuals. improvement of body composition by decreasing fat weight to normal level and so decrease body weight to ideal weight and steady of free fat body weight which led to increasing muscular tissue.
\end{abstract}

Key Word : energy, aerobic, anaerobic ability, defense, hand ball players

Introduction:

$\mathrm{H}$ and ball is considered one of the activity which characterized by special aspect as it withed a great interest in the last years because of its exciting, it became in an advanced position between the competitive games ( Olympics - universally - internationally - local ) as it developed bigger and fast science its beginning until our day from technical and legal view, so naturally this developing requires a similar development in scientific planning in physical training field .

So if the training programs and systems were planed properly, this will result in developing body composition to the player and so its performance level, and so the physiological adaptation process . [2]

Abed El Rahman Zaher (2011) assures that physical training leads to physiological changes necessary to physical performance, and the player performance level depend on the positivity of this changes ( aerobic and anaerobic) which achieve adaptation of the body organs to face the effort and physical stress as a result of training and competitions . [ 13 ]

Kamal Darwish et all (1998) refers that succeful coach is the one who is aware of the physiological influences as a result of training endurance on his players so he can control this endurances to guarantee its positive influences either volume of intensity, which appear in the developing the different a aspects, especially skills , planning and physical aspects, and reaching higher sportive levels . [ 14 ]
Abo El Ela Abed - El Fatah (2003) assures that energy production systems and its development became the modern physical training language and the direct inference to increase sportive performance level without wasting ( losing ) effort and time which is dome in other training directions away from specific sportive performance.

Bruce and Noble (1986) refers that in most of the sportive activity both aerobic and anaerobic systems work together but it doesn't means that one is nat predominate on the other according to the practiced activity . [ 23 ]

Abo El-Ela Abed El Fatah adds that hand ball players depend on anaerobic system by $60 \%$ and aerobic by $40 \%$. [ 3 ]

Kamal Darwish et all (1998) assures that the nature of performance in hand ball in which the player use running and sprint which leads to diversity of energy production systems in the body between anaerobic energy an speedy movements and aerobic energy on movements for long time . [ 14 ]

The amount of energy of a hand ball player depends on many factors, the most important player weight, hight, age , neuromuscular system condition and its co-ordination with hormonal system, in addition to the effort as the amount of energy production increases during physical effort twice as in rest according to the effort done . [ 14 ]

Abo El Ela Abed - El Fatah and Sobhy Hassanin (1997) refer that body composition adds a new aspect to the player to understand himsey as the precise measuring of body 
composition gives valuable information's in determinations of ideal weight that enable the player to reach the sportive pick which is necessary in adaptation with training. [ 5 ]

Mohammed Naser El Din Radwan (1997) mentioned that increased fat in the body leads to obesity which has a negative influence on performance in several physical activity as fats has no positive role to the production of muscle power, also studies and scientific researches should that physical performance improves in individuals when body fat percent decrease especially in activities required muscular power . [ 18 ]

The researcher sees that hand ball depend mostly on a player characterized in body composition as it is increased in museular mass and decreased in fat percent in order to improve performance level, Avo El Ela Abed El Fatah (1999) refers that hand ball player after modrerate training endurance . requires $10-12 \mathrm{hrs}$ to return to metabolic level while it requires $36-42 \mathrm{hrs}$ when using intense training endurance . [ 2 ]

Mohammed El Hamahmy (2000) refers that body composition os one of the facters that affect metabolism as it increase as the muscular tissue increase and vice versa for peaple with obesity because fat tissue considerd adormant centers for oxidization of nutrional elements. [ 17 ]

From the researcher experience, he naticed team player of 6 - October city club vorn in 1994 after aperiod of time during competitions differ from player to another as signs of fatigue start to appear which naticed through movements and faild defence aiming ( throwing ) and also many mistakes in defence, slow in taking attack chances despite the efficiency of skillful performance of the p;ayers which led the researcher to try to overcome this negaive phenomena and trying to develop aerobic ability, also giving the players coordinat body cimposition so they can increase the metabolic rate, that now it came the importance of body composition of hand ball player, and then the influence of developing aerobic and anaerobic ability to endure attack performance and body composition of team player of 6 - October city club born in (1994) Jonhand ball . which led the researcher to consider doing this study and using this as research problem .

\section{Amis:}

The research aims to designing a suggested training program according to energy production systems and identifying the following:

1 - The Effect of training program an aerobic and anaerobic ability hand ball players .

2 - The Effect of training program on enduring defense performance hand ball players .

3 - The Effect of training program on body composition hand ball players .

\section{Methodology:}

The researcher used experimental method because of its convienience to the nature of the study.

\section{Sample:}

The researcher sample included of ( 32 ) player were chosen of 6- October city club born in (1994), The standerd sample were (20) player in addition to pilot study sample were ( 12 ) player from El - Madi Club Born in ( 1994 ) for sportive season 2012 - 2013 in addition, the choose of ( 12 ) player from El- Madi club born in (1992), to identify the significant difference between them and pilot study sample for validity, The Mean of Age $18.159 \pm 1.019$, the high $174.313 \pm 7.119$ and the weight $74.344 \pm 4.857$

\section{Measuring aerobic and anaerobic ability :}

- $\quad$ Measuring aerobic ability test ( $\mathrm{VO} 2 \max$ ). [22] [23] [24]

- Measuring anaerobic ability test (wengat ) . [ 19 ]

\section{Defense performance endurance test}

- Movement performance edurance test.

- $\quad$ Precise shooting on gool test.

- Throwing medican ball $1 \mathrm{Kg}$. to the gongerst distance.

- Jumping from static test .

\section{Measuring Body compoition :}

Measuring weight and hight and apparatus of a Body composition analyzer 300 - TBF to measure body composition and then get five variables whicha are fat percent, fat weight, body weight without fat, accepted fat weight, Ideal weight in addition to the whole body weight .

\section{Pre-measurement:}

The researcher applied the pre measurement to the research sample in physiology lab in faculty of physical education Monofia university for the variable of age - hight - weight , aerobic and anaerobic ability and body composition in 2-62012 to 5-6-2012 preparing aerobic and anaerobic .

\section{Purpose of training program :}

The training program aims to developing aerobic and anaerobic ability and improving movement performance endurance under discussion and body cimposition of the research sample. [2] [4] [7] [12]

\section{Program application :}

The application of aerobic - anaerobic program starts durign training sessions at 9-6-2012 to 18-8-2012 .

\section{Post measurment :}

The post measurement were conducted to the individual of research sample uner the same conditions of pre- 
measurements after the end of program application at $25-8 \quad-2012$ to $29-8-2012$.

\section{Results}

Table ( 1 )

ANOVA, significant and percentage between the per, interval and post measures .

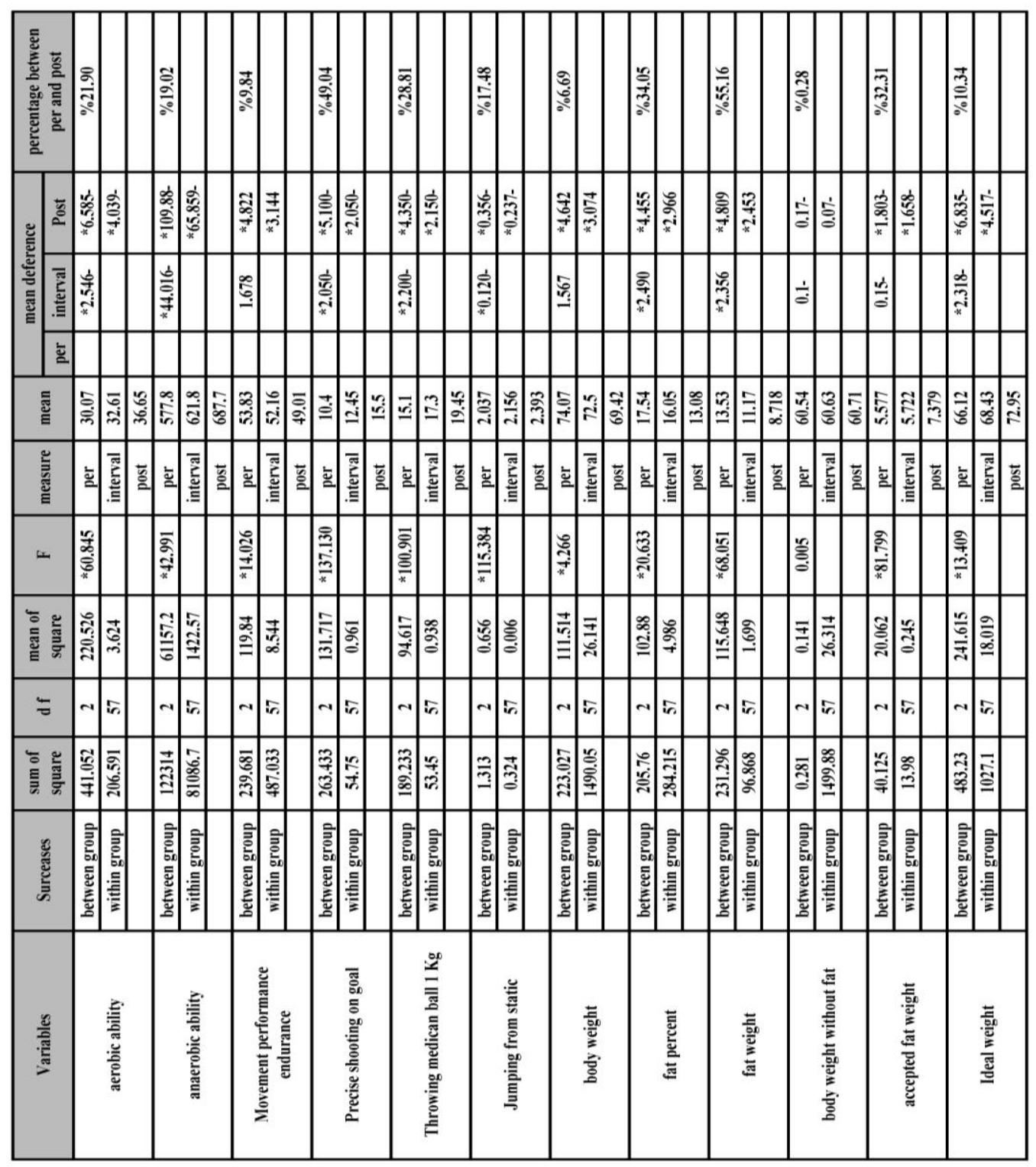




\section{Discussion:}

Table (1) There is a percentage of improvement in this variavle to the post measurement on the same sequence by $21.90 \%, 19.02 \%$ the researcher explains the differences and the improvement of the experimental group to the suggested aerobic - anaerobic training program which was applied by using the ggh and low intense interval training .

Abo El Ela abed el Fatah , Ahmed naser El Din (1993) refer that ( VO2 max) express the aerobic ability of the body and that the muscular system is the determinent factor of the aerobic human capacity not the process of transporting O2 to the muscles .[4] , El Sayed Abed El Magusod saaures that supply the mscle with energy by the aerobic work leads to thegrowth of the muscle fiber, also increase intensity under anaerobic conditions with the increasing of recovery period lead to muscle hypertrophy . [ 8 ], Through the results of the same study from decreasing fat and body weight and the steady of fat less body which means increasing muscular tissue and this explains the improvement of aerobic - anaerobic ability of the research sample individuals .

The results of table ( 1 ) there is percentage of improvements in this variables for post measurements on the same sequence by $9.84 \%, 49.04 \%, 28.81 \%, 17.31 \%$ the researcher explaines that the superiorty of research sample in movement performance endurance test and precise shooting on goal and throwing medical ball $1 \mathrm{Kg}$ to the longerst distence and jumping from static in the post measurement to the pre measurements due to the application of aerobic - anaerobic program .

Abo El Ela Abed El Fatah(1997),Talha Hossam El Din et all(1997) agreed that determined the percentage of participating of energy aroduction system and its relation with players performance level and its development is the direct interence to increase performance level and so reaching the gigh of performance . [1] [11]

Through the caring of the researcher of thr resting intervals during and after training sessions and application of aerobic - anaerobic program which aims to develop aerobic anaerobic ability through using effective endurance, so we can give training endurances more during single time period so that we can increase general traning endurance an so increasing repeating performance movement performance shooting on goal, arms and legs muscular ability which have the greater impact on the applied test results, the research adds that repeating attack performance endurance related with speedy recovery and the hand ball player gaining this endurance so he can perform arms and legs movements during skills fastly and power fully and be able to continue in performing through competition .

Abo El Ela Abed El Fatah , Sobhy Hassanin (1997) mentiand that there is an opposite relative between sportive performance ( Movement performance efficiency) and body fat percent, Abo El Ela Abed E Fatah , Ahmed Naser El Din (1993)add that body weight wighout gat related usually with sportive performance level because its increase means increasing of muscular mass which is required to most of sportive activity.[5][3], The explains the improvement of variable of attack performance endurance under discussion dur to improvement of body composition.

In table ( 1 ) results there is percentage of improvement in this variables for the post measurements on the same sequence by $6.69 \%, 34.05 \%, 55.16 \%, 0.28 \%, 32.31 \%$, $10.34 \%$ The researcher explains this improvement and this statistical significant to the training program, specially the nature of aerobic training which has direct influence on fats as aerobic training has tends to be for linger times with decreasing rest a source of energy sypply to the muscle during longer periods of action, while variable of body weight without fat the results did not show significant difference between pre-post measurements despite the improvement of post measurement than pre measurements. The researcher explains this lack of difference that the variable of body weight without fat tends to steady or increasing due to continous training which leads to burning a large amount of fats and then decrease in fat weight and increase in muscle weight and it is adaptation for mscular work leads to increasing muscular fibers and increase in muscle intersction which explains increasing body weight without fat or even keeping weight with the increase of muscular mass dur to the relative relation between power and muscle volume but the amount of fat decrease in not equal to amount of increase but much less than that. which led to significant imrovement in fats htrough weight and percentage and non-significant imprvement in body weight without fat

This results agreed with what Mohammed Ali Ahmed (1996) has mentiond as stated by lamb (1984) that sportive training leads to decrease in voulume of fat cells nat is count . this exp;ains the decrease of fat percentage and weight at current study sample, also fat decrease may be due to the lost of calories during sportive training.[16], With the decrease of fat percentage and increasing free fat body weight, this percentage agreed with the percentage mentioned by Abo El Ela Abed Fatah , Ahmed Naser El Din (1993) That Fat percentage in male 13-15\% in the age 16-25 years which fits greatly with age group of research sample.[4], The results of Ahmed Naser El Din , Rafek Haron (1996) indicates that there is a positive relation between body weight without fat and maximum anaerobic ability and also there is a negative relation between body weight and anaerobic ability component . [6 ]

This agreed with what revered to by Abo El Ela Abed El Fatah, sobhy Hassanin ( 1997 ) that sportive training leads to major changes in body composition even its concentrated on a specific part of the body as it will with drow the fats in all its storage in body not only the part that has been practiced and redistributed in a another form . [ 5 ] 


\section{Conclusions:}

1. There is a significant statistical difference between the averages of per and post for the post measurements in improving aerobic and anaerobic ability for hand ball players .

2. There is a significant statistical difference between the averages of per and post for the post measurements in the variables of attack performance endurance for hand ball players .

3. There is a significant statistical difference between the averages of per and post for the post measurements in body weight, fat percentage, fat weight, accepted fat weight and ideal weight , while there is no statistical significant difference In free fat body weight for hand ball players .

4. The increasing in performance improvement according to measuring unit in aerobic and anaerobic ability and attack performance endurance ( movement performance endurance shooting on goal - medical ball throwing $1 \mathrm{Kg}$ for the longest distance - jumping from static ) for research sample individuals .

5. Improvement of body composition by decreasing fat weight to normal level and so decrease body weight to ideal weight and steady of free fat body weight which led to increasing muscular tissue .

\section{Recommendation:}

1. When planning a training program there should be determination and controlling training endurance ( percentage of work periods to rest according to energy production systems ) to suites the player abilities and considering individual differences between them .

2. The importance of coaches applying physical and skillful training program so they controlled aerobic and anaerobic for hand ball players .

3. The gain of hand ball players co-ordinate body composition so that they have the ability to increase the metabolic rate .

4. Using active positive rest during recovery to keep blood flow and supply muscle with food, oxygen and speedy disposal of lactic acid, so that increasing focus on technical performance and decreasing tense of stress and anxiety .

5. The necessary providing of potentials to achieve means of measuring aerobic and anaerobic on perfect aspect.

\section{Reference:}

1. Abo Ela Ahmed Abed el- Fattah (1997) : Athletic Training - physiological foundations, Dar Al-Fikr Al Arabi, Cairo . P. 30 .
2. Abo Ela Ahmed Abed el- Fattah (1999) : hospitalization in the sports field, Dar Al-Fikr Al Arabi, Cairo. P.12,65,68:72 .

3. Abo Ela Ahmed Abed el- Fattah ( 2003): Physiology of Training and Sports, Dar Al-Fikr Al Arabi , Cairo . P. 306 , 83 .

4. Abo Ela Ahmed Abed el- Fattah, Ahmed Nasr el din sayed (1993) : Physiology of fitness, the Arab Thought Dar, Cairo . P. 270,239,373.

5. Abo Ela Ahmed Abed el-Fattah, Mohamed Sobhy Hassanein (1997) : Physiology and morphology Sports and methods of measurement and evaluation, Dar Al-Fikr Al Arabi , Cairo . P. 295:324, 380, 361:369 .

6. Ahmed Nasr el din sayed, Haron Rafik Abd el Wahab (1996) : Some indicators anaerobic and aerobic capacity and their relationship to the installation of the body, research published in the journal ( Physical Education and Sports ) Faculty of Physical Education for Boys in Cairo, Helwan University, Issue 25 April.

7. Amr Alla Ahmed El Bisatti (1998) : Principles and rules of sports training and applications, Monshait El Maaref, Alexandria. P. 82 .

8. El Sayed Abed el-Maksoud, Amer (1997) : Theories of athletic training (strength training and physiology), center of the book for publication, Cairo . P. 13:14

9. Samer Youssef Meteb El chammkhi ( 2007 ) : The impact of anaerobic exercises in the evolution of bearing strength and speed with young players in handball, Journal of the Science of Physical Education, Faculty of Physical Education, University of Babylon, Iraq .

10. Sarab Akram Lotf Allah ( 2011 ) : aerobic and anaerobic efficiency and its relationship to the performance of my skills accurately transmit and beating overwhelming volleyball, Journal of the Science of Physical Education, Faculty of Physical Education for Girls , University of Babylon, Baghdad.

11. Talha Hossam El Din , Wafaa Salah el-Din , Mostafa Kamel Hamad, Said Abed el Rashid (1997) : Scientific Encyclopedia in athletic training, center of the book for publication, Cairo . P. $18: 19$.

12. Abbas Abed el Fattah el ramly (1993) : Fencing " epee,", Dar El Fekr El Arabi, Cairo. P. 88 : 89.

13. Abed el Rahman Zaher (2011) : Encyclopedia of Sports Physiology, Center for book publishing, Cairo . P. 161

14. Kamal al-Din Darwish, Abbas Imad al-Din , Sami Mohammed Ali (1998) : the physiological bases for the training of Handball, center for book publication, Cairo . P. 17,19,37.

15. Mohamed Abed el Moneim Mahmoud (2000) : The effect of the proposed training program for the development of the aerobic and anaerobic work on offensive skills and some physical and physiological variables for basketball players , Master , Faculty of Physical Education Sadat, Menoufia University .

16. Mohammed Ali Ahmed (1996) : The role of training in hierarchical development of muscle strength and physical composition of their relationship and the achievement of digital swimmers for short distances for Young, Journal of Sports Science and Arts College of Physical Education for Girls , Cairo

17. Mohamed Mohamed el - hamahmy (2000) : Nutrition and Health for Life and Sports, Center for book publishing, Cairo .

18. Mohamed Nasr El Din Radwan (1997) : the reference in the physical measurements, Dar El Fekr el Arabi, Cairo . P. $213: 214$ 
19. Mohamed Nasr El Din Radwan (1998) : Methods of measurement of physical effort in the sport, center for book publication, Cairo .P. 141:143 .

20. Adams Gene M., (1994): Exercise Physiology Laboratory, Manual, $2^{\text {nd }}$ Ed, Wm. C. Brown Co, U.S.A.

21. Ana Cláudia Fernandez, Marco Túlio de Mello, Sérgio Tufik, Paula Morcelli de Castro and Mauro Fisberg (2004): Influence of the aerobic and anaerobic training on the body fat mass in obese adolescents, Rev Bras Med Esporta - Vol. $10, \mathrm{~N}^{\mathrm{o}} 3$-Mai/Jun.

22. Baumgartner Ted A., Andrew S., Jackson, (1995): Measurement for Evaluation in physical education and Exercise Science, Houghton Mifflin Co, U.S.A. P. 279
23. Bruce, J., Nobil (1986): physiology of exercise and sports. tines mirror / Mosby collage publishing, st Louis Toronto, Santa, dara . P. 11,140.

24. Heyward, Vivian H., (1998): Advanced Fitness Assessment \& Exercise Prescription, $3^{\text {rd }}$ ed. Burgess publishing Co, U.S.A. P. $56: 57$.

25. Luiz Cláudio R., Cirillo Everton Luis R., Frisselli Ariobaldo, Dourado Antonio C., (2005): Short and long term adaptation in anaerobic peak power in Brazilian soccer players, European college of sport science, Belgrade, 13-16 July.

26. Ward Smith Al December (1999): Aerobic and anaerobic energy Conversion during high-intensity exercise. Country of publication united states 
